\title{
Integrated Management of Mungbean Yellow Mosaic Virus (MYMV) Disease in Jharkhand, India
}

\author{
Praveen Kumar* and S.M. Prasad \\ Jharkhand Rai University, Ranchi Jharkhand, India \\ *Corresponding author
}

\section{A B S T R A C T}

\section{Keywords \\ Mungbean yellow mosaic virus, \\ Insecticide, \\ Mungbean, \\ Whitefly vector, \\ Integrated disease \\ management}

\section{Article Info}

Accepted:

20 December 2020

Available Online:

10 January 2021
Mungbean Yellow Mosaic Virus (MYMV) disease is one of the most serious diseases of green gram Vigna radiata (L.) in India. In nature, this disease is spread through the whitefly vector, Bemisia tabaci Genn. This research paper reports the result of field trials on management of the MYMV disease by Cultural, Chemical and Biological methods. Integration of seed treatment with insecticides imidacloprid 17.8 SL @ 3ml/kg and foliar spray of imidacloprid 17.8 SL @ 0.5/lit sprayed on 25 DAS and 40 DAS respectively, recorded highest plant height $(76.33 \%)$ during 2018 and $(78.45 \%)$ during 2019 and higher grain yield $(9.05 \mathrm{q} / \mathrm{ha})$ and the lowest incidence of MYMV $(17.90 \%)$ diseases and whitefly populations (18.13/ plant on $20 \mathrm{DAS}, 2.44$ / plant on $30 \mathrm{DAS}$, and 2.97/plant on 45 DAS. It was found to be the best with regards to no. of pods/plants 22.51 during $2018 \& 23.72$ during 2019, pod length 9.45 during 2018 and 9.73 during 2019 and no. of seeds per pod 11.11 during 2018 \& 12.24 during 2019. The subsequent efficacious treatment was integration of seed treatment with insecticide based chemical compound, Spinosad and foliar sprays of spinosad sprayed on 25 DAS and 40 DAS provided plant height $(72.45 \%)$ during $2018 \&(74.12 \%)$ during 2019, no. of pods/plants 21.23 during $2018 \& 21.67$ during 2019, pod length 9.07 during 2018 \& 9.57 during 2019, no. of seeds per pod 10.44 during 2018 \& 11.31 during 2019 and grain yield $(8.59 \mathrm{q} / \mathrm{ha})$ with the disease incidence of MYMV (19.60\%) and whitefly populations (20.94/plant on 20 DAS, 2.47/plant on 30 DAS, and 3.40/plant on 45 DAS, followed by integration of seed treatment with the insecticide, Dimethoate $(\mathrm{ml} / \mathrm{kg})$ and foliar sprays of Dimethoate $(1.5 \mathrm{ml} / \mathrm{lit})\left(\mathrm{T}_{3}\right)$ sprayed on 25 DAS and 40 DAS provided plant height (70.85\%) during 2018 \& $(72.67 \%)$ during 2019, no. of pods/plants 19.33 during 2018 \& 20.33 during 2019, pod length 8.44 during 2018 \& 8.84 during 2019, no. of seeds per pod 9.55 during 2018 \& 10.61 during 2019 and grain yield $(8.65 \mathrm{q} / \mathrm{ha})$ with the disease incidence of MYMV $(20.27 \%)$ and whitefly populations (20.04)/plant on $20 \mathrm{DAS}, 2.52$ / plant on $30 \mathrm{DAS}$, and 3.25/plant on $45 \mathrm{DAS}$.

\section{Introduction}

Mungbean, Vigna radiata (L.) wilczek is a major pulse crop grown widely in the south and southeast Asia, especially on a smallscale family-owned farms. Mungbean is native to India-Burma region of South-East Asia. In India MYMV disease is a major 
constraint in mungbean production (Nene, 1988; Dubey, 2003; Dubey and Singh, 2013) and the humid tropical areas of Southeast Asia (Iwaki and Auzay, 1978). The incidence of Mungbean yellow mosaic virus (MYMV) disease was first reported from IARI, New Delhi, India by Nariani, 1960. Subsequently, the disease has been reported from all over India and other countries of the South Asia by Varma and Malathi, 2003. Rishi, 2009 reported that MYMV disease occurrence in farmers field might be as high as 100 per cent in India. Amin and Singh (1987) observed that in susceptible cultivars the losses caused by MYMV disease was estimated up to 47 per cent.

The furthermost actual way to minimize the impact of MYMV is to grow resistant varieties. Still, none of the known Indian varieties has been reported to be fully resistant to MYMV (Varma et al., 1998), other management options such as insecticidal sprays, bio-agents and cultural practices are mandatory to manage the whitefly vector of the virus. The incidence of MYMV in Mungbean was the lowest in crops raised from the seeds treated with thiamethoxam (Ganapathy and Karuppiah, 2004). Hence, the present studies, the main objective was to evaluate insecticides alone and in combination with other insecticides and the bio-agents in different modes of application so as to develop a vital approach for the management of the disease.

\section{Materials and Methods}

At Krishi Vigyan Kendra (KVK), Hazaribagh, Jharkhand, field trials were led in demonstration Farm during 2018-2019 and 2019-2020 in Kharif seasons. Hazaribagh lies on $620 \mathrm{~m}$ above sea level, climate of hazaribagh is classified as warm \& temperate. The summer season are much rainy than the winters. The average temperature in
Hazaribagh is $23.7^{0} \mathrm{c}^{-}$The annual rainfall is $1274 \mathrm{~mm}$. The soil of experimental field was loamy sandy red soil. The physicochemical properties of the soil included Organic Carbon - 0.57 (Medium), N- 228.0 kg/ha, P$13.67 \mathrm{~kg} / \mathrm{ha}, \mathrm{K}-125.0 \mathrm{~kg} / \mathrm{ha}, \mathrm{S}-12.5 \mathrm{~kg} / \mathrm{ha}$, pH 5.72.

The trials were conducted using the susceptible mungbean variety, SML 668 and included nine treatments tested under Randomized Block Design. Treatment details were as follows:

$\mathrm{T}_{1}$-Seed treatment with the insecticide, Imidacloprid 17.8 SL (3ml/kg of seed) + Two foliar spray with Imidacloprid $(0.5 \mathrm{ml} / \mathrm{lit})$,

$\mathrm{T}_{2}$-Seed treatment with insecticide based chemical compound, Spinosad ( $1 \mathrm{ml} / \mathrm{kg}$ of seed) + Two foliar spray with Spinosad (0.5 $\mathrm{ml} / \mathrm{lit}$ ),

$\mathrm{T}_{3}$-Seed treatment with the insecticide, Thiomethoxam $(5 \mathrm{~g} / \mathrm{kg}$ of seed $)+$ Two foliar spray with Thiomethoxam $(0.5 \mathrm{~g} / 1 \mathrm{lit})$, $\mathrm{T}_{4^{-}}$Seed treatment with the insecticide, Dimethoate $(5 \mathrm{ml} / \mathrm{kg}$ of seed $)+$ Two foliar spray with Dimethoate $(0.5 \mathrm{ml} / \mathrm{lit})$,

$\mathrm{T}_{5^{-}}$Seed treatment with the bioagent, Verticillium lecani $(5 \mathrm{~g} / \mathrm{kg}$ of seed) + Two foliar spray with Verticillium lecani (5 g/lit),

$\mathrm{T}_{6}$ - Seed treatment with Rhizobium culture

$\mathrm{T}_{7}$ - Maize as border row (2 row),

$\mathrm{T}_{8}$ - Marigold as trap crop + yellow sticky trap (8/ha), T9- Control.

Other experimental details included, replications-3, Plot size of $3 \times 1.5 \mathrm{~m}^{2}$ and spacing of $30 \times 10 \mathrm{~cm}^{2}$. Spraying of insecticides was undertaken at intervals of 25 and 40 days after sowing. All the recommended agronomical practices like application of recommended dosage of fertilizer, cultural operations were followed except measures for insect pest management. Sprayings was done during morning hours. Observations were recorded at 15 days after 
first and 15 days after second sprays and the data obtained were analyzed statistically.

In each treatment ten plants were selected randomly, in every plant three trifoliate leaves each from top, middle and bottom canopies were taken into a polythene cover. The samples were taken to the laboratory, by using stereo zoom microscope the live population of nymphs were counted. Data on whitefly population was recorded before and after spraying \& taken at 20 DAS, 30 DAS followed by 45 DAS. In each plot randomly ten plants were selected and observations were recorded. Per cent disease incidence of YMV was recorded from the whole plot at 40 DAS followed by 55 days after sowing from all the treatments. Action of dissimilar insecticides on the incidence of MYMV disease was calculated in terms of percent disease incidence by using the following formula. The plants from respective plot were harvested separately and the seed yield was recorded. The data thus obtained subjected to ANOVA after using proper transformations.

Percent disease incidence $=$

Number of infected plants in a row
Percent Protection $=\frac{\text { MYMV disease incidence in control }- \text { MYMV disease incidence in treatment }}{\text { MYMV disease incidence in control }} \times 100$

For recording observations, five plants were randomly selected from each treatment in every replication and detailed observations were recorded on the different quantitative characters when the plants were fully grown. Plant height was recorded from ground level to the tip of the plant in centimetres at the time of maturity. Total number of pods borne on every plant was counted at the time of maturity. Numbers of seeds per pod were counted per plants. Length of pods was measured per plants. Thousand seed weight (gm) was recoded after complete drying. Seed yield per plant and 100 seed weight per plant determined in gram and grain yield were measured after harvesting of the crop.

In each plot, the total numbers of healthy plants, as well as virus-infected plants were counted separately. MYMV disease incidence was recorded at 15 days after first spray and 15 days after second spray and data were analysed statistically.

\section{Results and Discussion}

Comprehensive analysis of two year's data from the experiment conducted during 201819 and 2019-20. The result of application of both seed treatment and foliar sprays with insecticides was found to be significantly elevated to the control (Table 1, fig 1). After $1^{\text {st }}$ spray combination of seed treatment with insecticides (imidacloprid) 17.8 SL @ 3ml/kg and foliar sprays of imidacloprid 17.8 SL @ 0.5/lit $\left(\mathrm{T}_{1}\right)$ sprayed on 25 DAS and 40 DAS recorded the highest plant height $(76.33 \%)$ during 2018 and (78.45\%) during 2019 and higher grain yield $(9.05 \mathrm{q} / \mathrm{ha})$ with the lowest disease incidence of MYMV (17.90\%) and whitefly populations (18.13/plant on 20 DAS, 2.44 /plant on $30 \mathrm{DAS}$, and 2.97/plant on 45 DAS. It is found to be best with regards to no. of pods/plants 22.51 during 2018 \& 23.72 during 2019, pod length 9.45 during 2018 and 9.73 during 2019 and no. of seeds per pod 11.11 during $2018 \& 12.24$ during 2019. The proficiency of different chemicals was evaluated against MYMV, seed treatment with insecticide and their application provided initial protection to the seeds inside the soil and enhanced seed germination. It was observed that the seeds treatment with 0.5 per cent imidacloprid and two foliar spray with imidacloprid, the plants showed less disease development and whitefly infestation. Imidacloprid showed a better result compared to thiamethoxam (Dubey and Singh, 2006). 
Table.1 Integrated Disease Management of MYMV during Kharif Pooled Data 2018-19

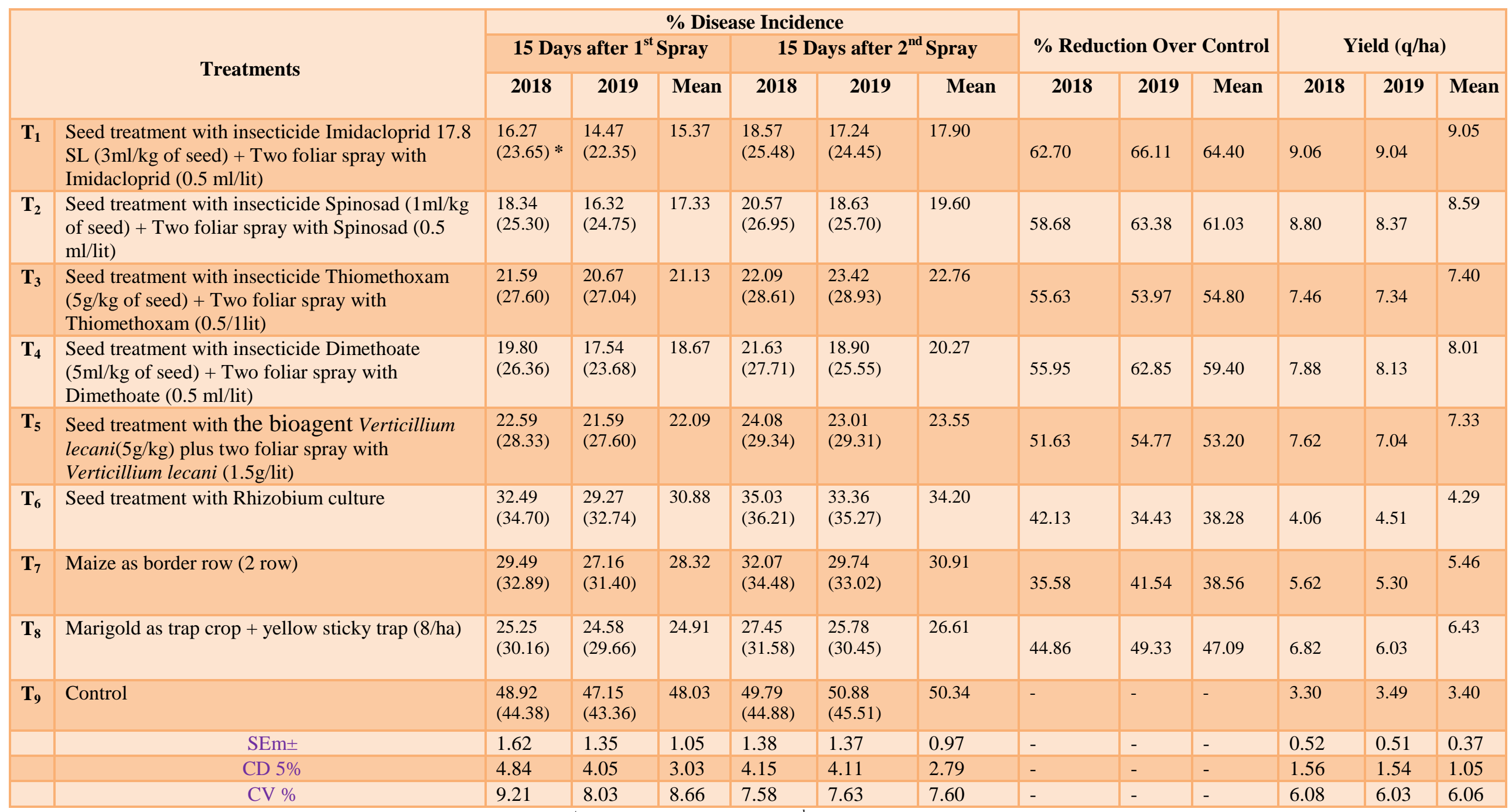

* Figures in parantheses are angular transformed values, $1^{\text {st }}$ Spray were taken at 25 and $2^{\text {nd }}$ Spray 40 days after planting.

ST- Seed Treatment, F.S- Foliar Spray 
Table.2 Population of whitefly, Bemisia tabaci in Integrated Disease Management of MYMV Kharif, 2018-19

\begin{tabular}{|c|c|c|c|c|c|c|c|c|c|c|}
\hline \multirow{2}{*}{\multicolumn{2}{|c|}{ Treatment }} & \multicolumn{3}{|c|}{$\begin{array}{l}\text { Whitefly (No.) at } 20 \\
\text { DAS }^{\star \star}\end{array}$} & \multicolumn{3}{|c|}{$\begin{array}{l}\text { Whitefly (No.) at } 30 \\
\text { DAS }\end{array}$} & \multicolumn{3}{|c|}{$\begin{array}{l}\text { Whitefly (No.) at } 45 \\
\text { DAS }\end{array}$} \\
\hline & & 2018 & 2019 & Mean & 2018 & 2019 & Mean & 2018 & 2019 & Mean \\
\hline $\mathbf{T}_{1}$ & $\begin{array}{l}\text { Seed treatment with insecticide Imidacloprid } 17.8 \mathrm{SL}(3 \mathrm{ml} / \mathrm{kg} \text { of seed })+\text { Two } \\
\text { foliar spray with Imidacloprid }(0.5 \mathrm{ml} / \mathrm{lit})\end{array}$ & $\begin{array}{l}18.50 \\
(4.36) *\end{array}$ & $\begin{array}{l}17.82 \\
(4.28)\end{array}$ & 18.16 & $\begin{array}{l}2.70 \\
(1.79)\end{array}$ & $\begin{array}{l}2.18 \\
(1.63)\end{array}$ & 2.44 & $\begin{array}{l}3.14 \\
(1.90)\end{array}$ & $\begin{array}{l}2.80 \\
(1.81)\end{array}$ & 2.97 \\
\hline $\mathbf{T}_{2}$ & $\begin{array}{l}\text { Seed treatment with insecticide Spinosad }(1 \mathrm{ml} / \mathrm{kg} \text { of seed })+\text { Two foliar spray } \\
\text { with Spinosad }(0.5 \mathrm{ml} / \mathrm{lit})\end{array}$ & $\begin{array}{l}21.45 \\
(4.67)\end{array}$ & $\begin{array}{l}20.36 \\
(4.56)\end{array}$ & 20.90 & $\begin{array}{l}2.43 \\
(1.71)\end{array}$ & $\begin{array}{l}2.50 \\
(1.73)\end{array}$ & 2.47 & $\begin{array}{l}3.68 \\
(2.04)\end{array}$ & $\begin{array}{l}3.13 \\
(1.89)\end{array}$ & 3.40 \\
\hline $\mathbf{T}_{\mathbf{3}}$ & $\begin{array}{l}\text { Seed treatment with insecticide Thiomethoxam }(5 \mathrm{~g} / \mathrm{kg} \text { of seed })+\text { Two foliar } \\
\text { spray with Thiomethoxam }(0.5 / 1 \text { lit })\end{array}$ & $\begin{array}{l}22.51 \\
(4.78)\end{array}$ & $\begin{array}{l}21.64 \\
(4.70)\end{array}$ & 22.07 & $\begin{array}{l}2.92 \\
(1.85)\end{array}$ & $\begin{array}{l}2.81 \\
(1.82)\end{array}$ & 2.87 & $\begin{array}{l}4.66 \\
(2.27)\end{array}$ & $\begin{array}{l}4.11 \\
(2.14)\end{array}$ & 4.39 \\
\hline $\mathbf{T}_{4}$ & $\begin{array}{l}\text { Seed treatment with insecticide Dimethoate }(5 \mathrm{ml} / \mathrm{kg} \text { of seed })+\text { Two foliar spray } \\
\text { with Dimethoate }(0.5 \mathrm{ml} / \mathrm{lit})\end{array}$ & $\begin{array}{l}20.91 \\
(4.63)\end{array}$ & $\begin{array}{l}19.21 \\
(4.43)\end{array}$ & 20.06 & $\begin{array}{l}2.60 \\
(1.76)\end{array}$ & $\begin{array}{l}2.43 \\
(1.71)\end{array}$ & 2.52 & $\begin{array}{l}4.11 \\
(2.14)\end{array}$ & $\begin{array}{l}3.25 \\
(1.93)\end{array}$ & 3.68 \\
\hline $\mathbf{T}_{\mathbf{5}}$ & $\begin{array}{l}\text { Seed treatment with bioagent Verticillium lecani }(5 \mathrm{~g} / \mathrm{kg}) \text { plus two foliar spray } \\
\text { with Verticillium lecani }(1.5 \mathrm{~g} / \mathrm{lit})\end{array}$ & $\begin{array}{l}19.61 \\
(4.48)\end{array}$ & $\begin{array}{l}18.64 \\
(4.37)\end{array}$ & 19.12 & $\begin{array}{l}3.78 \\
(2.06)\end{array}$ & $\begin{array}{l}3.32 \\
(1.95)\end{array}$ & 3.55 & $\begin{array}{l}5.23 \\
(2.39)\end{array}$ & $\begin{array}{l}4.24 \\
(2.18)\end{array}$ & 4.74 \\
\hline $\mathbf{T}_{6}$ & Seed treatment with Rhizobium culture & $\begin{array}{l}23.16 \\
(4.86)\end{array}$ & $\begin{array}{l}22.81 \\
(4.82)\end{array}$ & 22.98 & $\begin{array}{l}4.48 \\
(2.22)\end{array}$ & $\begin{array}{l}4.12 \\
(2.14)\end{array}$ & 4.30 & $\begin{array}{l}6.20 \\
(2.59)\end{array}$ & $\begin{array}{l}5.15 \\
(2.37)\end{array}$ & 5.67 \\
\hline $\mathbf{T}_{7}$ & Maize as border row (2 row) & $\begin{array}{l}26.80 \\
(5.22)\end{array}$ & $\begin{array}{l}24.92 \\
(5.02)\end{array}$ & 25.86 & $\begin{array}{l}3.57 \\
(2.02)\end{array}$ & $\begin{array}{l}3.25 \\
(1.94)\end{array}$ & 3.41 & $\begin{array}{l}6.46 \\
(2.62)\end{array}$ & $\begin{array}{l}5.46 \\
(2.44)\end{array}$ & 5.96 \\
\hline $\mathbf{T}_{8}$ & Marigold as trap crop + yellow sticky trap (8/ha) & $\begin{array}{l}24.76 \\
(5.02)\end{array}$ & $\begin{array}{l}22.59 \\
(4.80)\end{array}$ & 23.67 & $\begin{array}{l}3.90 \\
(2.09)\end{array}$ & $\begin{array}{l}3.14 \\
(1.90)\end{array}$ & 3.52 & $\begin{array}{l}5.92 \\
(2.53)\end{array}$ & $\begin{array}{l}4.59 \\
(2.26)\end{array}$ & 5.26 \\
\hline $\mathbf{T}_{9}$ & Control & $\begin{array}{l}27.44 \\
(5.28)\end{array}$ & $\begin{array}{l}26.77 \\
(5.21)\end{array}$ & 27.10 & $\begin{array}{l}7.23 \\
(2.78)\end{array}$ & $\begin{array}{l}7.07 \\
(2.75)\end{array}$ & 7.15 & $\begin{array}{l}9.44 \\
(3.15)\end{array}$ & $\begin{array}{l}7.44 \\
(2.81)\end{array}$ & 8.44 \\
\hline & $\mathrm{SEm} \pm$ & 0.21 & 0.20 & 0.15 & 0.08 & 0.08 & 0.06 & 0.09 & 0.10 & 0.07 \\
\hline & CD $5 \%$ & 0.64 & 0.61 & 0.42 & 0.25 & 0.25 & 0.17 & 0.28 & 0.29 & 0.19 \\
\hline & $\mathrm{CV} \%$ & 7.65 & 7.39 & 9.20 & 7.20 & 7.28 & 8.85 & 6.74 & 7.62 & 8.76 \\
\hline
\end{tabular}

* Figures in parantheses are angular transformed values, **DAS - Days after sowing. 
Table.3 Yield and Yield Attributes of Mungbean during Kharif, 2018

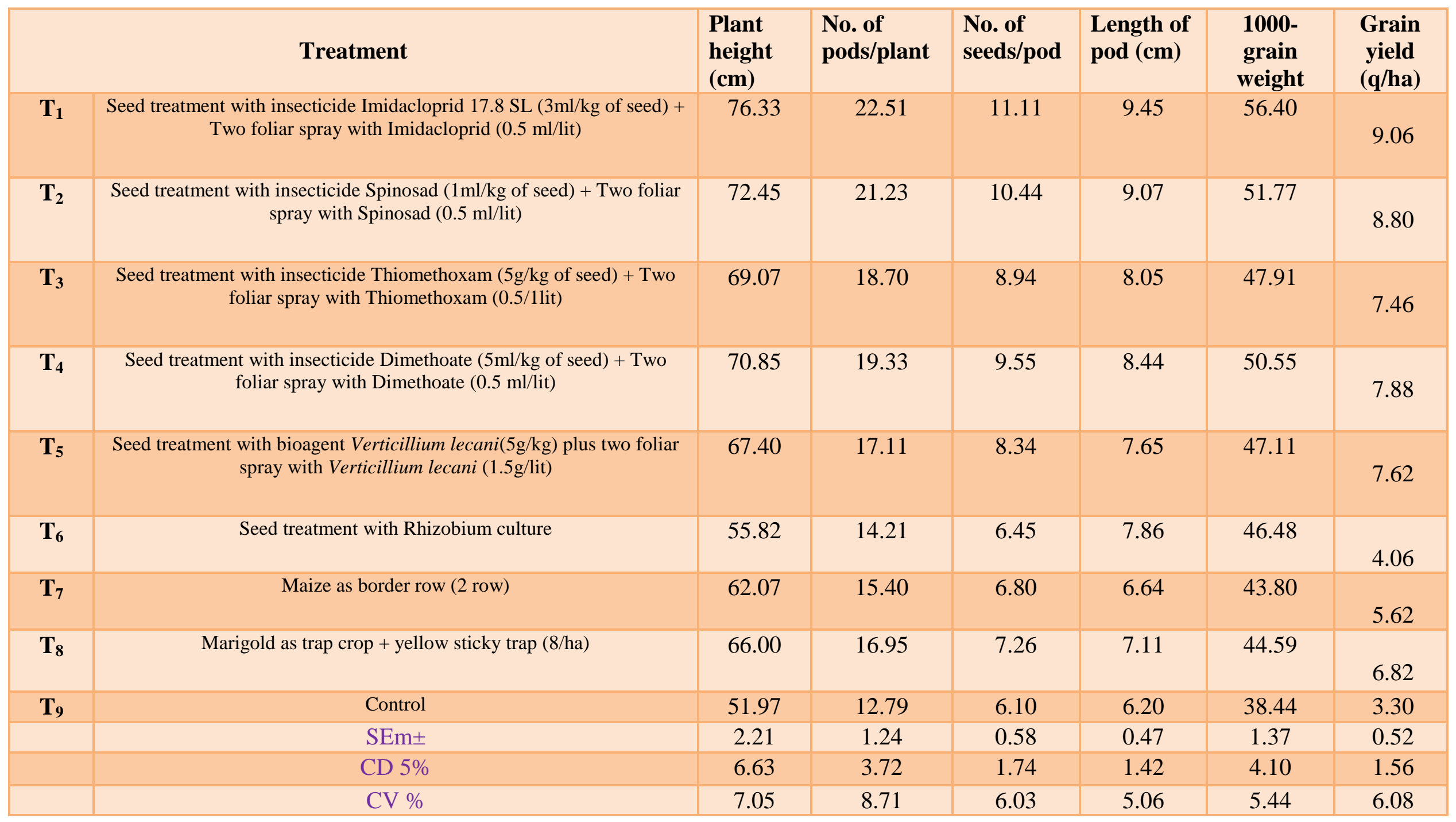


Table.4 Yield and Yield Attributes of Mungbean during Kharif, 2019

\begin{tabular}{|c|c|c|c|c|c|c|c|}
\hline \multicolumn{2}{|r|}{ Treatment } & \multirow{2}{*}{$\begin{array}{c}\begin{array}{c}\text { Plant height } \\
\text { (cm) }\end{array} \\
78.45\end{array}$} & \multirow{2}{*}{$\begin{array}{c}\begin{array}{c}\text { No. of } \\
\text { pods/plant }\end{array} \\
23.72\end{array}$} & \multirow{2}{*}{$\begin{array}{c}\begin{array}{c}\text { No. of } \\
\text { seeds/pod }\end{array} \\
12.24\end{array}$} & \multirow{2}{*}{$\begin{array}{c}\begin{array}{c}\text { Length of } \\
\text { pod }(\mathbf{c m})\end{array} \\
9.73\end{array}$} & \multirow{2}{*}{$\begin{array}{c}\text { 1000- } \\
\text { grain } \\
\text { weight } \\
58.20\end{array}$} & \multirow{2}{*}{$\begin{array}{c}\begin{array}{c}\text { Grain } \\
\text { yield } \\
\text { (q/ha) }\end{array} \\
9.04\end{array}$} \\
\hline $\mathbf{T}_{\mathbf{1}}$ & $\begin{array}{l}\text { Seed treatment with insecticide Imidacloprid } 17.8 \mathrm{SL}(3 \mathrm{ml} / \mathrm{kg} \text { of } \\
\text { seed })+ \text { Two foliar spray with Imidacloprid }(0.5 \mathrm{ml} / \mathrm{lit})\end{array}$ & & & & & & \\
\hline $\mathbf{T}_{2}$ & $\begin{array}{l}\text { Seed treatment with insecticide Spinosad }(1 \mathrm{ml} / \mathrm{kg} \text { of seed })+\text { Two } \\
\text { foliar spray with Spinosad }(0.5 \mathrm{ml} / \mathrm{lit})\end{array}$ & 74.12 & 21.67 & 11.31 & 9.57 & 52.10 & 8.37 \\
\hline $\mathbf{T}_{3}$ & $\begin{array}{l}\text { Seed treatment with insecticide Thiomethoxam }(5 \mathrm{~g} / \mathrm{kg} \text { of seed })+ \\
\text { Two foliar spray with Thiomethoxam }(0.5 / 1 \text { lit })\end{array}$ & 70.54 & 19.57 & 9.78 & 8.56 & 48.78 & 7.34 \\
\hline $\mathbf{T}_{4}$ & $\begin{array}{l}\text { Seed treatment with insecticide Dimethoate }(5 \mathrm{ml} / \mathrm{kg} \text { of seed })+ \\
\text { Two foliar spray with Dimethoate }(0.5 \mathrm{ml} / \mathrm{lit})\end{array}$ & 72.67 & 20.33 & 10.61 & 8.84 & 51.21 & 8.13 \\
\hline $\mathbf{T}_{\mathbf{5}}$ & $\begin{array}{l}\text { Seed treatment with bioagent Verticillium lecani }(5 \mathrm{~g} / \mathrm{kg}) \text { plus two } \\
\text { foliar spray with Verticillium lecani }(1.5 \mathrm{~g} / \mathrm{lit})\end{array}$ & 69.48 & 18.08 & 8.77 & 8.04 & 48.44 & 7.04 \\
\hline $\mathbf{T}_{6}$ & Seed treatment with Rhizobium culture & 58.67 & 15.53 & 7.01 & 8.38 & 47.15 & 4.51 \\
\hline $\mathbf{T}_{7}$ & Maize as border row ( 2 row) & 63.21 & 16.64 & 7.46 & 7.62 & 44.80 & 5.30 \\
\hline $\mathbf{T}_{\mathbf{8}}$ & Marigold as trap crop + yellow sticky trap (8/ha) & 68.73 & 17.52 & 7.79 & 6.90 & 45.26 & 6.03 \\
\hline \multirow[t]{4}{*}{$\mathbf{T}_{9}$} & Control & 55.16 & 14.33 & 7.10 & 7.57 & 38.77 & 3.49 \\
\hline & SEm \pm & 1.77 & 0.91 & 0.74 & 0.52 & 1.47 & 0.51 \\
\hline & $\mathrm{CD} 5 \%$ & 5.29 & 2.73 & 2.21 & 1.55 & 4.42 & 1.54 \\
\hline & $\mathrm{CV} \%$ & 5.50 & 6.19 & 7.32 & 5.36 & 5.80 & 6.03 \\
\hline
\end{tabular}




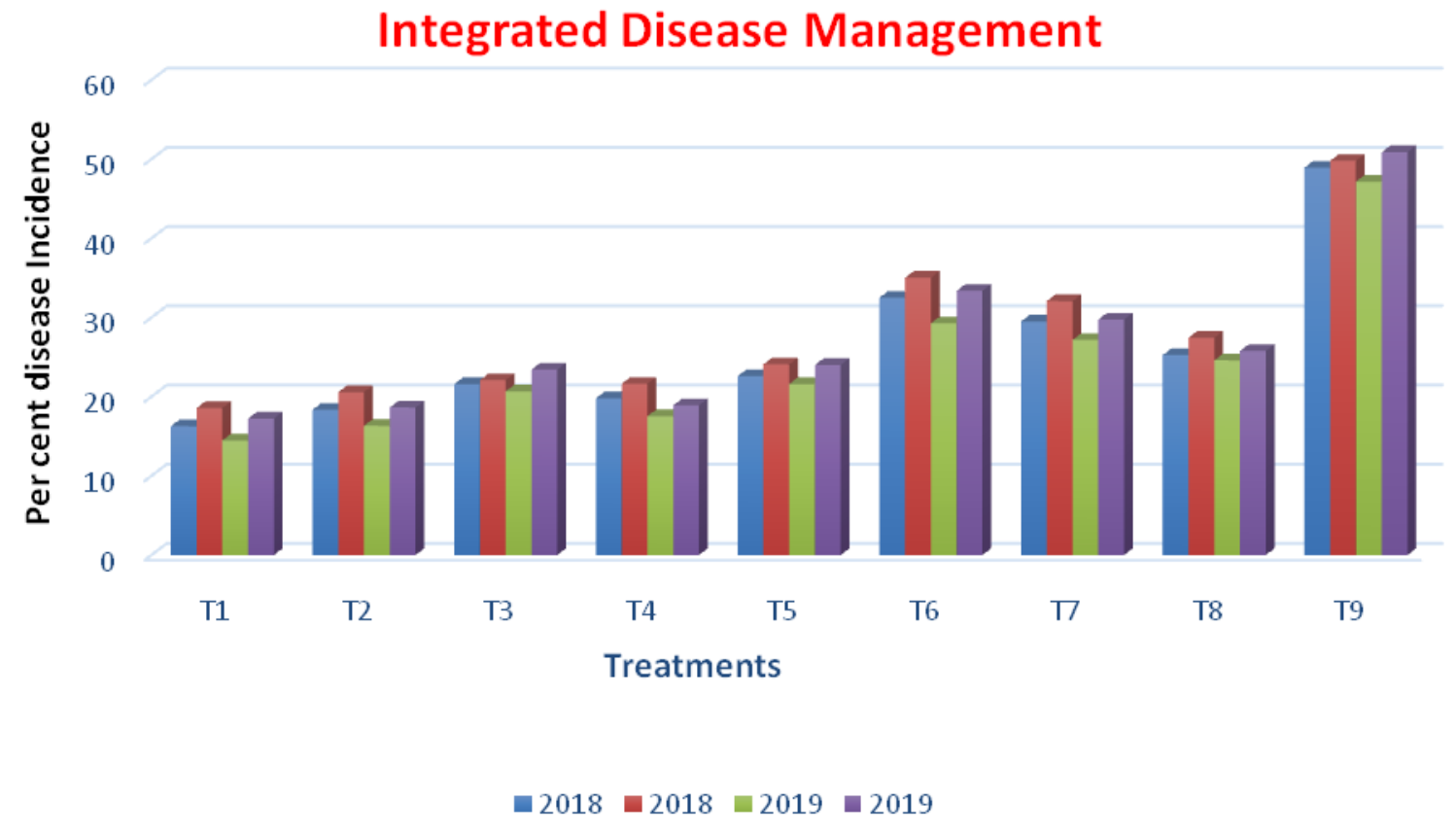

Fig.1 Integrated Disease Management of MYMV during Kharif Pooled Data 2018-2019

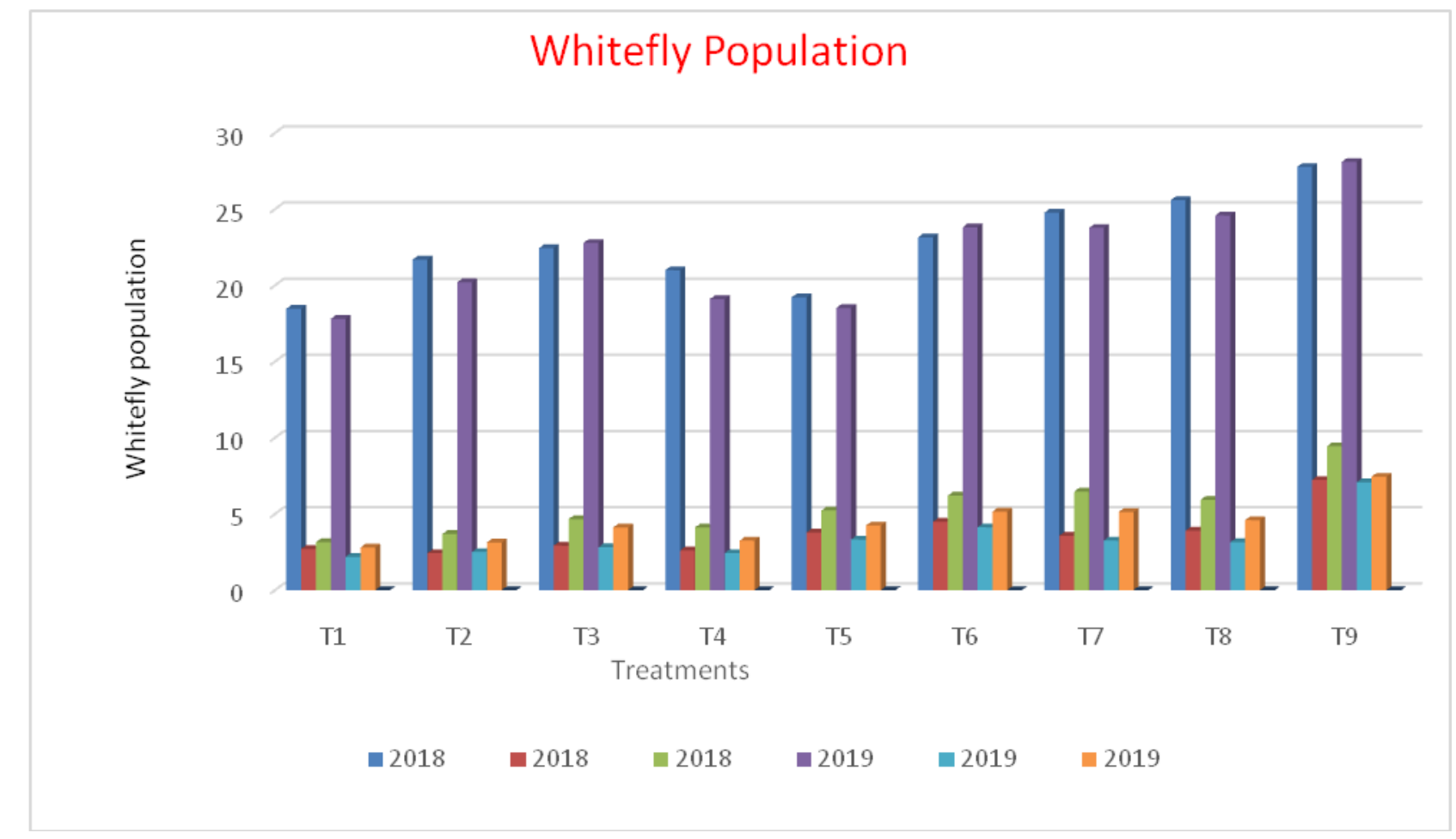

Fig.2 Population of whitefly, Bemisia tabaci (Gennadius) in Integrated disease management of MYMV 2018-19 
Hence, imidacloprid was selected for the present study. The next effective treatment was combination of seed treatment with Spinosad and foliar sprays of Spinosad $\left(\mathrm{T}_{2}\right)$ sprayed on 25 DAS and 40 DAS provided plant height (72.45\%) during 2018 \& (74.12\%) during 2019, no. of pods/plants 21.23 during $2018 \& 21.67$ during 2019, pod length 9.07 during $2018 \& 9.57$ during 2019, no. of seeds per pod 10.44 during 2018 \& 11.31 during 2019 and grain yield $(8.59 \mathrm{q} / \mathrm{ha})$ with the disease incidence of MYMV (19.60\%) and whitefly populations (20.94 per plant on 20 DAS, 2.47 per plant on 30 DAS, and 3.40 per plant on $45 \mathrm{DAS}$, followed by combination of seed treatment with dimethoate $(5 \mathrm{ml} / \mathrm{kg})$ and foliar sprays of dimethoate $(1.5 \mathrm{ml} / \mathrm{lit})\left(\mathrm{T}_{3}\right)$ sprayed on 25 DAS and 40 DAS provided plant height (70.85\%) during 2018 \& (72.67\%) during 2019, no. of pods/plants 19.33 during 2018 \& 20.33 during 2019, pod length 8.44 during 2018 \& 8.84 during 2019, no. of seeds per pod 9.55 during 2018 \& 10.61 during 2019 and grain yield $(8.65 \mathrm{q} / \mathrm{ha})$ with the disease incidence of MYMV (20.27\%) and whitefly populations (20.04) per plant on 20 DAS, 2.52 per plant on $30 \mathrm{DAS}$, and 3.25 per plant on 45 DAS. Treatment $T_{1}, T_{2}$ and $T_{3}$ were statistically similar. Maize as border row was found ineffective \& recorded an incidence of 30.91 per cent with lowest yield $(5.46 \mathrm{q} / \mathrm{ha})$, no. of pod per plant 15.40 during 2018 \& 16.64 during 2019, pod length 6.64 during $2018 \& 7.62$ during 2019 and no. of seeds per pod 6.80 during 2018 \& 7.46 during 2019 followed by Rhizobium culture recorded an incidence 34.20 per cent with yield (6.52 q/ha), no. of pod per plant 14.21 during 2018 \& 15.53 during 2019, pod length 7.86 during $2018 \& 8.38$ during 2019, no. of seeds per pod 6.45 during $2018 \& 7.01$ during 2019 (Table 1, 2, \& 3 Figs. 1\& 2).

The most common vector for MYMV is whitefly which was effectively managed by
Imidacloprid, Spinosad (Yadav and Singh, 2014), and dimethoate (Yadav et al., 2015). For minimizing the whitefly population, scheduled spray of imidacloprid on 25 and 40 DAS was most effective found. Two sprays of Spinosad on 25 and 40 DAS was found more effective then imidacloprid for minimizing whitefly population as well as MYMV disease management.

Varma et al., (1992) recorded 100 per cent incidence of MYMV disease in farmer's field and this disease often caused significant yield losses. Karthikeyan et al., (2014) reported yield loss of up to 85 per cent. More establishment of whitefly population has been reported due to delay in spraying, due to which reduction of vector borne diseases becomes more difficult (Dubey and Singh, 2013). From the present findings it is clear that an integrated application of cultural, insecticides and bio-control agent in different ways could be found an effective strategy for the management of mungbean diseases.

\section{References}

Amin, K.S., Singh, R.A., (1987). Disease of mung, urd and pea and their management. In: Proceedings of National Seminar on Plant Protection in Field Crops, CPPTI, Hyderabad, India from 29-31 Jan. 1986, pp. 203-217.

Dubey, S.C., (2003). Integrated Management of web blight of urd/mung bean by bioseed treatment. Indian Phytopathol. 56, 34-38.

Dubey, S. C., Singh, B., (2006). Integrated management of Cercospora leaf spots and yellow mosaic of urdbean (Vigna mungo). Indian J. Agric. Sci. 76, 485489.

Dubey, S.C. and Singh, B., (2010). Seed treatment and foliar application of insecticides and fungicides for management of Cercospora leaf spots 
and yellow mosaic of mungbean (Vigna radiata). Int. J. of Pest Management. 56(4): 309-314.

Dubey, S.C. and Singh, B., (2018). Integrated management of wet root rot, yellow mosaic, and leaf crinkle diseases of urdbean by seed treatment and foliar spray of insecticides, fungicides and biocontrol agent. Crop Protection 112: 269-273.

Ganapathy, T., Karuppiah, R., 2004. Evaluation of new insecticides for the management of whitefly (Bemisia tabici Genn.) Mungbean yellow mosaic virus (MYMV) and urdbean leaf crinkle virus (ULCV) disease in munbean (Vigna radiate (L.) Wilczek). Indian J. Plant Prot.32, 35-38.

Fleming, R. and. Retnakaran, A., (1985). Evaluation of single treatment data using Abott's formula with reference to insects. Indian Journal of Economic Zoology.,78: 1179-1181.

Iwaki, M., Auzay, H., (1978). Virus disease of mungbean in Indonesia. In: Cowell, R. (Ed.), The $1^{\text {St }}$ International Munbean Symposium. The office of the information Services, AVRDC, Taiwan, pp. 169-172.

Karthikeyan, A., Shobhana, V.G., Sudha, M., Raveendran, M., Senthil, N., Pandiyan, M., Nagarajan, P., (2014). Mungbean yellow mosaic virus (MYMV): a threat to green gram (Vigna radiata) production in Asia. Int. J. Pest Manag. 60, 314-324.

Nariani, T.K., (1960). Yellow mosaic of mung (Phaseolus aureus L.) Indian
Phytopathol. 13, 24-29.

Nene, Y.L., (1988). Multiple disease resistant in grain legumes. Annu. Rev. PhytoPathol. 26, 203-217.

Rishi, Narayan, (2009). Significant plant virus disease in India and a glimpse of modern disease management technology. J. Gen. Plant Pathol. 75, 118.

Varma, A., Dhar, A.K., Mandal, B., (1992). MYMV transmission and control in India. In: In: Green, S.K., Kim, D. (Eds.), Mungbean Yellow Mosaic Disease Asian Vegetable Research and Development Center, Taipei, Taiwan. 8-27.

Varma, A., Mandal, B., Malathi, V.G., (1998). Putative location of common region and coat protein gene of black gram isolate of mungbean yellow mosaic Gemini virus, J. Plant Biochem. Biotechnol.7, 7-12.

Varma, A., Malathi, V.G., (2003). Emerging geminivirus problems: a serious threat to crop production. Ann. Appl. Biol. $142,145-164$.

Yadav, N.K., Singh, P.S., (2014). Bioefficacy of chemical insecticides against spotted pod borer, Maruca testulalis (geyer) on cowpea. Int. J. Agric. Environ. Biotechnol. 7, 187-190.

Yadav, S.R., Kumawat, K.C., Khinchi, S.K., (2015). Efficacy of new insecticide molecules and bioagents against sucking insect pests of cluster bean, Cyamopsis tetragonoloba (Linn.) Taub. Legume Res. 38, 407-410.

\section{How to cite this article:}

Praveen Kumar and Prasad, S.M. 2021. Integrated Management of Mungbean Yellow Mosaic Virus (MYMV) Disease in Jharkhand, India. Int.J.Curr.Microbiol.App.Sci. 10(01): 3555-3564. doi: https://doi.org/10.20546/ijcmas.2021.1001.420 